\title{
Utilization of Sawdust in Concrete Masonry Blocks: A Review
}

\author{
SAJJAD ALI MANGI*, NORWATI BINTI JAMALUDDIN*, ZUHAIB SIDDIQUI*, \\ SHEERAZ AHMED MEMON**, AND MOHD HAZIMAN BIN WAN IBRAHIM*
}

RECEIVED ON 12.10.2017 ACCEPTED ON 17.08.2018

\begin{abstract}
SDC (Sawdust Concrete) was developed in $19^{\text {th }}$ century. It has been well recognized due to its lightweight and cost-effectiveness. Presently, developed countries have created opportunities to use wood waste in the concrete construction to reduce the environmental burden. Although SDC has received little consideration as a lightweight masonry block in building works but it has been intensively investigated in many countries for decades. The aim of this review is to summarize the last five years (2012-2016) research work related to utilization of sawdust in concrete masonry. However, it is important to explore existing ideas and approaches developed by previous researchers as a reference and guidance for the future research. There are lots of opportunities to develop lightweight concrete especially throughutilizing sawdust as a fine aggregate replacement material in concrete. However, this review paper is focusing on utilization of sawdust, as to reduce environmental impacts poses by the waste products of furniture industry and a by-product of wood industry. As a conclusion, this review paper summaries the existing important ideas and useful information for the fellow researchers, as to enhance the utilization of sawdust to produce lightweight masonry units. It is recommended that considerable research is required on the sawdust cement blocks, which can deliver more confidence on their utilization as a green building construction material.
\end{abstract}

Key Words: Sawdust, Fine Aggregate, Concrete, Compressive Strength, Masonry Blocks.

\section{INTRODUCTION}

$\mathrm{D}$

ue to rapid growth of industrialization, the industrial waste creates the environmental and economic problem associated to their disposal. During the recent years there has been increasing focus on the application of discarded items and by-products from numerous sources in building works. Along with the environment protection, numerous studies were conducted on recycling of waste products as construction resources. Utilization of such waste materials into the building works could be a feasible answer not only to the pollution problem, but also to the challenge to high cost of construction materials which are being faced by many developing countries. One of such important waste is the sawdust which is comparatively plentiful and economical.

Sawdust is waste produced by timber industries, obtained from cutting, sawing or grinding of timber in the form of particle Fig. 1. Sawdust incorporated in cement has been familiar as 'sawdust cement' [1]. However, the development of sawdust concrete is still under investigation.

\footnotetext{
Authors E-Mail: (sajjad.nec@gmail.com, norwati@uthm.edu.my, zuhaib@neduet.edu.pk, sheerazahmed.memon@faculty.muet.edu.pk, haziman@uthm.edu.my)

* $\quad$ Faculty of Civil \& Environmental Engineering, Universiti Tun Hussein Onn Malaysia,Malaysia

** Institute of Environmental Engineering \& Management, Mehran University of Engineering \& Technology, Jamhoro, Pakistan.
}

This is an open access article published by Mehran University Research Journal of Engineering and Technology, Jamshoro under the CC by 4.0 International License. 
Some of researchers have focused utilization of sawdust with additive materials, chemicals, waste materials, light weight aggregate, sand replacement. However, this paper highlights the possible use of sawdust in masonry concrete blocks as a sand replacement adopted by former researchers from Nigeria, Ghana, Brazil, China, Iraq, Turkey, UK, India, Philippines, France and Malaysia. It is expected that this information can be useful for the new researchers to discover more on sawdust concrete.

\section{PRETREATMENT OF SAWDUST}

Although sawdust consists largely of cellulose, comprises soluble sugar, acids, resins, oils and waxes, and extra organic materials. These extractable substances affect the setting of cement, particularly in lean mixes. So, irregular deviations of properties in various kinds of sawdust, the only safe process is to conduct trial tests of available sawdust to observe whether it has desired strength can be produced. Pre-treatment of sawdust is, therefore, essential to ensure that extractable materials in the sawdust do not affect hardening process of the cement. Lime need to be added as 1/6-1/3 volume per volume of cement to the sawdust earlier to mixing [2,7].

\section{REVIEW OF PREVIOUS RESEARCH}

The summary of literature reviews of published articles since 2012-2016 has been presented in Tables 1-5. Tables 1-5 are showing previous research work carried out on SDC to develop the lightweight, cost effective, durable

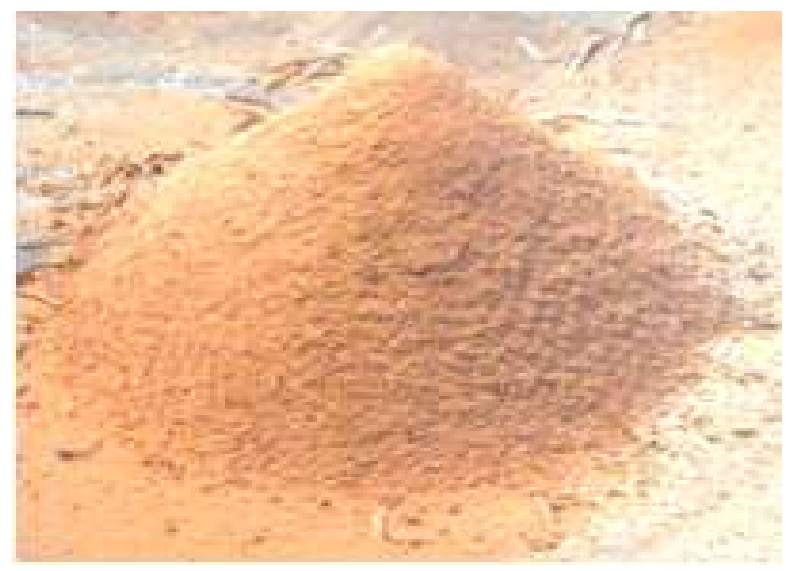

FINE SAWDUST PARTICLES and environmental friendly material for the construction industry. It was observed that the utilization of SDC has a wide capability, use as a sand replacement in concrete which reduces the environmental pollution and creates solution to the sustainable construction material to build cost effective structures.

\section{DISCUSSION ON PREVIOUS FINDINGS}

Sawdust pre-treatment is, therefore, necessary to ensure that extractable materials in the sawdust do not affect the hardening process of the cement. Two methods of pretreatment has been discussed by Saeed [7]: boiling sawdust in lime added water and addition of waterproofing material diluted in kerosene to sawdust, the better results were found with second method. According to Paramasivam and Loke [2] the optimum socking time for 'Kempus' sawdust was found to be 60 minute earlier to mixing. However, lime is added 1/6-1/3 volume per volume of cement to the sawdust [2].

Physical properties are the basic characteristics of wood and it is behavior to external influences other than applied forces. This includes grain and texture, density, moisture content, dimensional stability, thermal behavior etc. Awareness of physical properties is thus important, because they can significantly influence the performance and strength of the material used in the structural applications: higher the amount of sawdust lower is the workability $[3,5,13,17]$.

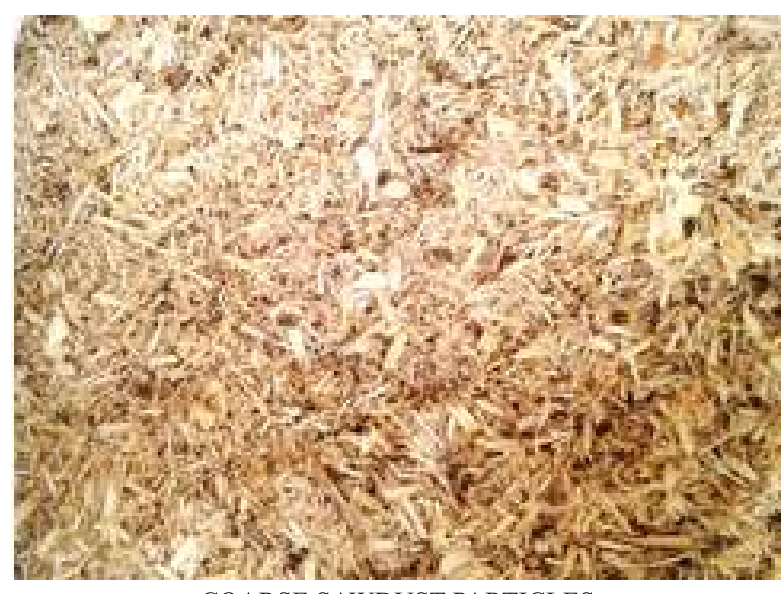

COARSE SAWDUST PARTICLES

FIG. 1. TYPICAL SAWDUST PARTICLES

Mehran University Research Journal of Engineering \& Technology, Volume 38, No. 2, April, 2019 [p-ISSN: 0254-7821, e-ISSN: 2413-7219] 
TABLE 1. SUMMARY OF PERVIOUS RESEARCH WORK CARRIED OUT IN YEAR 2012

\begin{tabular}{|c|c|c|c|c|}
\hline Reference & Country & $\begin{array}{l}\text { Replacement of Material \& } \\
\text { Mix Design Procedure }\end{array}$ & Block Properties & Research Findings \\
\hline Adebakin andAdeyemi [3] & Nigeria & $\begin{array}{l}0,10,20,30 \text { and } 40 \% \text { by } \\
\text { volume of sand in } \\
1: 8 \text { mix. Used water curing } \\
\text { for } 7,14,21 \text { and } 28 \text { days }\end{array}$ & Hallow (150mm x 450mm) & $\begin{array}{l}\text { Compressive strength was found } 4.26 \text { to } 1.80 \\
\mathrm{~N} / \mathrm{mm} 2 \text { for } 0 \text { to } 40 \% \text { sand replacement. } \\
10 \% \text { reduction in weight were observed at } 10 \% \\
\text { sawdust replacement and about } 3 \% \text { reduction in } \\
\text { production cost. }\end{array}$ \\
\hline Akinwonmi [4] & Ghana & $\begin{array}{l}0,20,40,65,80 \text { and } \\
100 \% \text { by weight of sand in } \\
1: 2 \text { mix. Used water curing } \\
\text { for } 7,14 \text { and } 28 \text { days }\end{array}$ & Solid $(100 \times 100 \times 100 \mathrm{~mm})$ & $\begin{array}{l}\text { The optimum replacement of sand with sawdust was } \\
\text { found to be } 20 \% \text { and Flexural strength were } \\
\text { observed } 15.9 \mathrm{~N} / \mathrm{mm} 2 \text { at } 28 \text { day. }\end{array}$ \\
\hline Moreira et. al. [5] & Brazil & $\begin{array}{c}5 \% \text { by weight of sand in } \\
1: 2.5: 2.5,1: 3.5: 3.5,1: 4: 4 \text { and } \\
1: 5: 5 \text { concrete mixes. } \\
\text { Used water curing for } \\
7 \text { and } 28 \text { days }\end{array}$ & Hallow (size not mentioned) & $\begin{array}{l}\text { Trial tests for the mass unit proportion, the different } \\
\text { proportions of fine and coarse aggregates were } \\
\text { taken }(20 / 80,25 / 75,30 / 70,35 / 65,50 / 50 \text { and } \\
60 / 40) \text { and good results were found on } 50 / 50 \\
\text { proportion. } \\
1: 4: 4 \text { proportion was found economical and } 6.45 \\
\text { MPa compressive strength was observed at } 28 \text { day. }\end{array}$ \\
\hline
\end{tabular}

TABLE 2. SUMMARY OF PERVIOUS RESEARCH WORK CARRIED OUT IN YEAR 2013

\begin{tabular}{|c|c|c|c|c|}
\hline Reference & Country & $\begin{array}{l}\text { Replacement of Material \& } \\
\text { Mix Design Procedure }\end{array}$ & Block Properties & Research Findings \\
\hline Cheng et. al. [6] & China & $\begin{array}{l}0,3,5,7 \text { and } 10 \% \text { by } \\
\text { weight of sand. Used } \\
\text { water curing for } \\
7 \text { and } 28 \text { days }\end{array}$ & $\begin{array}{l}\text { Solid Blocks }(100 \times 100 \times 100 \\
\mathrm{mm})\end{array}$ & $\begin{array}{l}\text { The optimum replacement of sand with sawdust was } \\
\text { found to be } 5 \% \text {. There is a great tendency towards } \\
\text { decreases the thermal conductivity and increases the } \\
\text { heat preservation and insulation property in sawdust } \\
\text { concrete. }\end{array}$ \\
\hline Saeed [7] & Iraq & $\begin{array}{l}0,5,10,15,20,25,30 \\
\text { and } 35 \% \text { by weight of } \\
\text { cement in } 1: 1 \text { mix. } \\
\text { Used water curing for } \\
28 \text { days }\end{array}$ & $\begin{array}{c}\text { Solid cubes } \\
(100 \times 100 \times 100 \mathrm{~mm}) \\
\text { and Prisms } \\
(100 \times 100 \times 500 \mathrm{~mm})\end{array}$ & $\begin{array}{l}\text { Bond between pretreated sawdust and cement } \\
\text { paste is increased due to washing out harmful } \\
\text { extractives in sawdust which inhabits setting and } \\
\text { hardening of surrounding cement paste. Thus } \\
\text { properties of SDC were highly being improved using } \\
\text { pretreated sawdust. } \\
\text { The compressive and Flexural strength were found } \\
\text { increasing up to } 50 \% \text { for sawdust. Water absorption } \\
\text { and thermal conductivity were highly be reduced. }\end{array}$ \\
\hline Turgut and Gumuscu [8] & Turkey & $\begin{array}{c}0,10,20 \text { and } 30 \% \\
\text { by volume of cement } \\
\text { and ratio cement to lime } \\
\text { powder waste as } \\
1: 5,1: 6 \text { and } 1: 7\end{array}$ & $\begin{array}{c}\text { Solid Brick } \\
\text { (For compressive } \\
105 \times 90 \times 75 \mathrm{~mm} \text { ) } \\
\text { (For Flexural } \\
105 \times 225 \times 75 \mathrm{~mm} \text { ) } \\
\text { (For unit weight } \\
105 \times 90 \times 75 \mathrm{~mm} \text { ) }\end{array}$ & $\begin{array}{l}\text { Found } 38.9 \% \text { reduction in the thermal conductivity } \\
\text { at } 30 \% \text { wood sawdust waste replacement with lime } \\
\text { powder waste and found decreases in the modulus } \\
\text { of elasticity at } 10,20 \text { and } 30 \% \text { wood sawdust waste } \\
\text { replacement } 3.2,27 \text { and } 46.6 \% \text { as compared with } \\
\text { normal mix. }\end{array}$ \\
\hline Aigbomian and Fan [9] & UK & $\begin{array}{c}\text { Sawdust } \\
\text { (Cedar, Pine, } \\
\text { Oak and Beech) } \\
\text { with lime }\end{array}$ & $\begin{array}{c}\text { Solid Blocks } \\
(100 \times 100 \times 100 \mathrm{~mm})\end{array}$ & $\begin{array}{l}\text { The average compressive strength was observed for } \\
\text { hardwood (Beech and Oak) sawdust as } 3.75 \text { and } \\
2.07 \mathrm{MPa} \text { respectively, for softwood (Pine and } \\
\text { Cedar) sawdust } 1.3 \text { and } 0.15 \mathrm{MPa} \text { respectively and } \\
\text { for mixed wood } 0.20 \mathrm{MPa} \text {. } \\
\text { Wood Crete made through mixed sawdust } \\
\text { highlighted } 18 \% \text { reduction in density as compared } \\
\text { to wood Crete made through hardwood and } 0.08 \% \\
\text { increase in density compared to wood Crete made } \\
\text { from softwood. }\end{array}$ \\
\hline
\end{tabular}


TABLE 3. SUMMARY OF PERVIOUS RESEARCH WORK CARRIED OUT IN YEAR 2014

\begin{tabular}{|c|c|c|c|c|}
\hline Reference & Country & $\begin{array}{l}\text { Replacement of Material \& } \\
\text { Mix Design Procedure }\end{array}$ & Block Properties & Research Findings \\
\hline Boob [10] & India & $\begin{array}{c}0,5,10,15 \text { and } 20 \% \text { by } \\
\text { weight sand in } 1: 4,1: 6 \text { and } \\
1: 8 \text { mixes. Used two method } \\
\text { of curing sprinkler and gunny } \\
\text { bag curing for } 7,14 \text { and } \\
28 \text { days }\end{array}$ & $\begin{array}{c}\text { Solid Blocks } \\
(100 \times 100 \times 100 \mathrm{~mm})\end{array}$ & $\begin{array}{l}\text { With gunny bag curing method for } 1: 6 \text { ratio by } 15 \% \\
\text { sawdust replacement gives strength of } 4.5 \mathrm{~N} / \mathrm{mm} 2 \text {, } \\
\text { density is } 2000 \mathrm{~kg} / \mathrm{m} 3 \text {, which is reasonable and } \\
\text { economical to be used for the partition walls in frame } \\
\text { structure. } \\
\text { Two methods (sprinkler and gunny bag covered) of } \\
\text { curing were adopted to evaluate the effect of curing } \\
\text { and the result of gunny bag covered method was } \\
\text { observed the best results. }\end{array}$ \\
\hline Kumar et. al. [11] & India & $\begin{array}{c}0,10,15 \text { and } 20 \% \text { by } \\
\text { weight of sand in } \\
\text { 1:1.5:3 concrete mix. }(7 \text { and } \\
\text { 14days) }\end{array}$ & $\begin{array}{c}\text { Solid Blocks } \\
(100 \times 100 \times 100 \mathrm{~mm})\end{array}$ & $\begin{array}{l}\text { With } 0,10,15 \text { and } 20 \% \text { replacement of fine } \\
\text { aggregate with sawdust gives the compressive } \\
\text { strength values as } 20.59,18.15,18.30 \text { and } 2050 \\
\mathrm{~N} / \mathrm{mm} 2 \text { respectively at } 28 \text { day of curing. }\end{array}$ \\
\hline Tomas and Ganiron [12] & Philippines & $\begin{array}{c}0 \text { and } 100 \% \text { by weight of } \\
\text { sand in } 1: 2: 4 \text { concrete mix. } \\
\text { Used water curing for } 7,14 \\
\text { and } 28 \text { days }\end{array}$ & $\begin{array}{c}\text { Solid Blocks } \\
(100 \times 100 \times 100 \mathrm{~mm})\end{array}$ & $\begin{array}{l}\text { The compressive strength at } 28 \mathrm{day} \text { was found } 3122 \\
\text { psi which is lower than NMC ( } 4258 \mathrm{psi}) \text {, about } 10 \% \\
\text { reduction in weight and } 44 \% \text { cost saving for the } \\
\text { same volume of sand. }\end{array}$ \\
\hline Oyedepo et. al. [13] & Nigeria & $\begin{array}{l}0,25,50,75 \text { and } 100 \% \text { by } \\
\text { weight of sand } 1: 2: 4 \text { concrete } \\
\text { mix. Used water curing for } 7 \text {, } \\
14,21 \text { and } 28 \text { days }\end{array}$ & $\begin{array}{c}\text { Solid Blocks } \\
(100 \times 100 \times 100 \mathrm{~mm})\end{array}$ & $\begin{array}{l}\text { Workability of concrete was observed to be } \\
\text { decreasing as the percentage sawdust increases in } \\
\text { the mix. The slump values } 40,9,5,6 \text {, and } 15 \mathrm{~mm} \\
\text { were obtained at } 0,25,50,75 \text { and } 100 \% \\
\text { replacement of sand by sawdust respectively. } \\
\text { When the sand is replaced by sawdust at } 0,25,50 \text {, } \\
75 \text { and } 100 \% \text { results for compressive strength at } \\
\text { 28day were obtained as } 14.44,13.00,12.33,11.11 \\
\text { and } 10.57 \mathrm{~N} / \mathrm{mm} 2 \text { respectively. }\end{array}$ \\
\hline
\end{tabular}

TABLE 4. SUMMARY OF PERVIOUS RESEARCH WORK CARRIED OUT IN YEAR 2015

\begin{tabular}{|c|c|c|c|c|}
\hline Reference & Country & $\begin{array}{l}\text { Replacement of Material \& } \\
\text { Mix Design Procedure }\end{array}$ & Block Properties & Research Findings \\
\hline Ambiga [14] & India & $\begin{array}{c}0,10,20 \text { and } 30 \% \text { by } \\
\text { weight of sand in1:1.5:3 } \\
\text { concrete mix. Used water } \\
\text { curing for } 7,14,21 \text { and } \\
28 \text { days }\end{array}$ & $\begin{array}{c}\text { Solid Blocks } \\
(100 \times 100 \times 100 \mathrm{~mm})\end{array}$ & $\begin{array}{l}\text { When the sand is replaced by sawdust at } 0,10 \text {, } \\
20 \text {,and } 30 \% \text { results for compressive strength at } \\
28 \text { day were obtained as } 20.80,16.30,4.80 \text { and } \\
\quad 0.57 \mathrm{~N} / \mathrm{mm} 2 \text { respectively. } \\
\text { At } 10 \% \text { replacement of sand with sawdust gives } \\
\text { about } 10 \% \text { reduction in weight and } 3 \% \text { reduction } \\
\text { in production cost. }\end{array}$ \\
\hline Xing et. al. [15] & France & $\begin{array}{c}0,30,40,50 \text { and } 60 \% \text {.Used } \\
\text { water curing for } 7 \text { and } \\
28 \text { days }\end{array}$ & $\begin{array}{c}\text { Solid Blocks } \\
(100 \times 100 \times 100 \mathrm{~mm})\end{array}$ & $\begin{array}{l}\text { The apparent density of Poplar sawdust } 178 \mathrm{~kg} / \mathrm{m} 3 \\
\text { and Saturated and surface-dried density } 390 \mathrm{~kg} / \mathrm{m} 3 \text {. }\end{array}$ \\
\hline handana, and Mynuddin [16] & India & $\begin{array}{c}0,5,10,15 \text { and } 20 \% \text { by } \\
\text { weight in concrete mix } \\
1: 1.44: 3.16 \\
\text { adopted water curing for } 7 \\
\text { and } 28 \text { days }\end{array}$ & $\begin{array}{c}\text { Solid Blocks } \\
(100 \times 100 \times 100 \mathrm{~mm}) \\
\text { and Cylinders } \\
\varnothing 100 \mathrm{~mm} 200 \mathrm{~mm})\end{array}$ & $\begin{array}{l}\text { When the sand is replaced by sawdust at } 0,5,10 \text {, } \\
15 \text { and } 20 \% \text { the average results for compressive } \\
\text { strength at } 28 \text { day were obtained as } 27.78,25.24 \text {, } \\
21.42,16.44 \text { and } 10.58 \mathrm{~N} / \mathrm{mm} 2 \text { respectively and the } \\
\text { tensile strength was observed as } 3.18,3.11 \text {, } \\
2.55,1.77 \text { and } 1.36 \mathrm{~N} / \mathrm{mm} 2 \text {. } \\
\text { The concrete with } 10 \% \text { sawdust was proved to be } \\
\text { optimum and cost effective. }\end{array}$ \\
\hline
\end{tabular}


The density of sawdust largely depends on the species of wood. Due to hydrophilic nature, the density of sawdust generally varies from $650-1650 \mathrm{~kg} / \mathrm{m}^{3}$. The density of sawdust concrete also varies depending upon the type and amount of sawdust used in mix. Using 'Kempas' wood, the dry density of sawdust concrete has been found to be 1490,930 and $850 \mathrm{~kg} / \mathrm{m}^{3}$ for the mixes with cement to sand ratios of $1: 1,1: 2$ and 1:3 respectively [2]. However, the density of concrete containing sawdust from rubber tree exhibited 1450,1280 and $1065 \mathrm{~kg} / \mathrm{m}^{3}$ respectively for the same mix proportions [17]. It can be seen that for higher amount of sawdust, the water absorption increased significantly $[10,20]$.

It is in general agreement that higher the amount, lower the strength development. Like mechanical properties, the compressive strength of concrete is greatly influenced by the type of sawdust in the mix. This has been reflected in the research findings of Paramasivam and Loke, [2] and Awal et. al. [17]. Paramasivam and Loke investigated the concrete containing 'Kempus' tree, where 28 day

TABLE 5. SUMMARY OF PERVIOUS RESEARCH WORK CARRIED OUT IN YEAR 2016

\begin{tabular}{|c|c|c|c|c|}
\hline Reference & Country & $\begin{array}{l}\text { Replacement of Material \& } \\
\text { Mix Design Procedure }\end{array}$ & Block Properties & Research Findings \\
\hline Awal et. al. [17] & Malaysia & $\begin{array}{c}1: 1,1: 2 \text { and } 1: 3 \text { cement to } \\
\text { sawdust by volume }\end{array}$ & $\begin{array}{c}\text { Solid Blocks } \\
\text { (100x100x100 mm) }\end{array}$ & $\begin{array}{l}\text { Slump were observed } 40 \mathrm{~mm}, 15 \mathrm{~mm} \text { and } 5 \mathrm{~mm} \text { for } \\
\text { mix proportions of } 1: 1,1: 2 \text { and } 1: 3 \text { respectively and } \\
\text { density of SDC at } 28 \text { days were found, for the mix } \\
\text { of } 1: 1,1: 2 \text { and } 1: 3 \text { are } 1450,1280 \text { and } 1065 \mathrm{~kg} / \mathrm{m} 3 \\
\text { respectively. } \\
\text { Compressive strength at } 28 \text { day were observed as } \\
18.65,17.20 \text { and } 12.80 \mathrm{~N} / \mathrm{mm}^{2} \text { for } 1: 1,1: 2 \text { and } 1: 3 \\
\text { respectively. } \\
\text { The tensile strength at } 28 \text { day were observed as } \\
2.05,1.95 \text { and } 1.30 \mathrm{~N} / \mathrm{mm}^{2} \text { for } 1: 1,1: 2 \text { and } 1: 3 \\
\text { respectively. } \\
\text { The flexural strength at the age of } 28 \text { day were } \\
\text { observed as } 2.75,2.20 \text { and } 1.90 \mathrm{~N} / \mathrm{mm}^{2} \text { for } 1: 1 \text {, } \\
1: 2 \text { and } 1: 3 \text { respectively. } \\
\text { The elastic modulus of } 17100,16400 \text { and } 11950 \\
\mathrm{~N} / \mathrm{mm}^{2} \text { were obtained for the mixes of } 1: 1,1: 2 \text { and } \\
1: 3 \text { respectively. }\end{array}$ \\
\hline Garcez et. al. [18] & Brazil & $\begin{array}{c}0,25,50,75 \text { and } 100 \% \text { by } \\
\text { volume of sand in concrete } \\
\text { mix. } 1: 2: 1.2\end{array}$ & $\begin{array}{c}\text { Solid cylinders } \\
\text { (Ø 50mmx100mm and } \\
\varnothing 100 \mathrm{~mm} \times 200 \mathrm{~mm})\end{array}$ & $\begin{array}{l}\text { Sand is replaced by sawdust at } 0,25,50,75 \text { and } \\
100 \% \text { the compressive strength at the age of } 28 \text { day } \\
\text { was observed as } 17.84,14.00,9.16,7.52 \text { and } 4.11 \\
\mathrm{~N} / \mathrm{mm}^{2} \text { respectively and the tensile strength were } \\
\text { observed as } 2.28,1.74,1.25,1.22 \text { and } 0.79 \\
\mathrm{~N} / \mathrm{mm} 2 \text {. }\end{array}$ \\
\hline Zakaria [19] & Malaysia & $\begin{array}{l}0,10,20,30,40,50,60 \\
\text { and } 70 \% \text { by volume of sand } \\
\text { in mix proportion of } 1: 2.25 \\
\text { for the water curing period of } \\
7 \text { and } 28 \text { days }\end{array}$ & $\begin{array}{c}\text { Solid Blocks } \\
(100 x 100 x 100 \mathrm{~mm})\end{array}$ & $\begin{array}{l}\text { Sawdust treating with } 2 \% \text { sodium hydroxide has } \\
\text { been shown to produce good results. } \\
\text { Silica fume used as admixture at } 3 \% \text { by cement } \\
\text { weight and Super plasticizer at } 1.5 \% \text { for all mixes to } \\
\text { maintain workability. } \\
\text { When sand is replaced by sawdust at } 0,25,50,75 \\
\text { and } 100 \% \text { the compressive strength at the age of } 28 \\
\text { day were observed as } 44.5,49.34,43.64,39.82 \text {, } \\
31.21,30.62,26.85 \text { and } 26.10 \mathrm{~N} / \mathrm{mm}^{2} \text { respectively } \\
\text { and the ultrasonic pulse velocity was observed as } \\
4265,4057,3985,3932,3652,3503 \text {, } \\
3365 \text { and } 3235 \mathrm{~m} / \mathrm{s} \text {. } \\
\text { It was detected that sawdust can be used as partial } \\
\text { replacement of sand from } 0-30 \% \text { contributes to } \\
\text { reduction ofwood waste without affecting concrete } \\
\text { strength. }\end{array}$ \\
\hline
\end{tabular}


compressive strength of $1: 3,1: 2$ and 1:1 mix of cement to sawdust were found to be 5.0, 8.7, 29.8 MPa respectively. Incorporating rubber sawdust, the compressive strength of sawdust concrete at the 28 day were found to be 18.65 , 17.20 and $12.8 \mathrm{MPa}$ respectively for the same mix proportions. Fig. 2 demonstrates a liner connection between the compressive strength and ultrasonic pulse velocity of SDC at 28 day.

Subsequently, it was perceived that the compressive strength of the concrete increased with increasing time of curing period. Obviously lower quantity of sawdust in the mix produced better results. Types of curing and length of curing period plays a vital role in the growth of concrete strength. Water curing has so far been widely practiced for curing of hydrated cemented concrete. Because of the very organic nature, concrete made with sawdust needs some modifications. It has been shown [10] that air curing at laboratory conditions produced better results as compared to the curing in immersed conditions. Similar behavior was observed in tension, flexure and modulus of elasticity of sawdust concrete $[4,10,17-18]$.

The tensile strength of SDC, were investigated though split cylinder test according to ASTM C496/C496M at 7, 14 and 28 day, and the findings were presented in Fig. 3. It was observed as like the compressive strength, tensile strength also reduced with the growth in the quantity of sawdust [17].

The connection between the compressive and tensile strength has been shown in Fig. 4. It was observed that compressive is relational to the tensile strength. Though, the value of the correlation reduces with the increase in sawdust amount.
All these research findings have, however, been limited to short-term study only. Along with strength investigation of masonry units of particular type, it is also important to study the strength behavior of the masonry wall [21].

Apart from the application in masonry units, the application of sawdust in developing lightweight concrete seems to be a distinctive solution not only to the environmental issue but also to the economic and green construction [22]. However, no experimental data are yet available on the structural performance of masonry wall using sawdust brick or blocks.

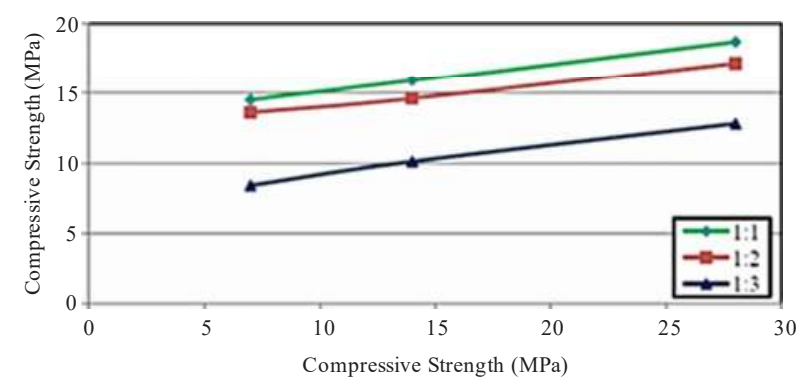

FIG. 2.COMPRESSIVE STRENGTH OF SDC

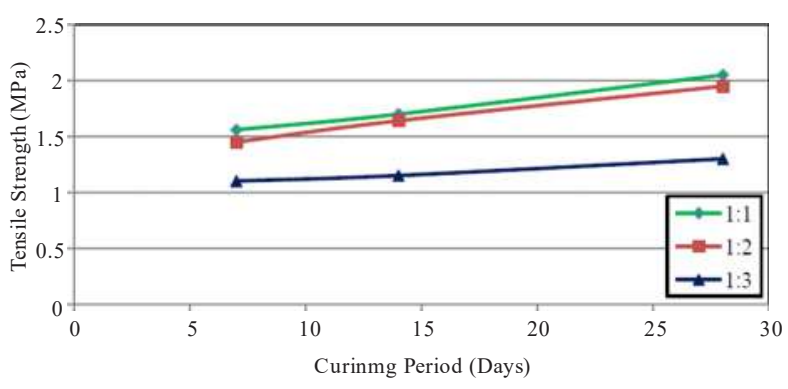

FIG. 3. SPLIT TENSILE STRENGTH OF SDC

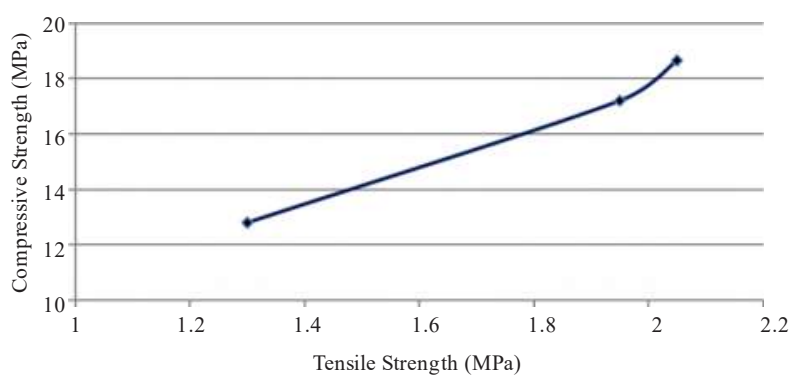

FIG. 4. COMPRESSIVE AND TENSILE STRENGTH RELASHIONSHIP FORSDC

Mehran University Research Journal of Engineering \& Technology, Volume 38, No. 2, April, 2019 [p-ISSN: 0254-7821, e-ISSN: 2413-7219] 


\section{CONCLUSION}

Based on the literature review of last five-year research studies from eleven countries on the sawdust utilization in the concrete, it was observed that the compressive strength and weight of concrete decreases as the percentage of sawdust increases and water-cement ratio increases as the percentage of sawdust increases in the mix. Earlier research, suggested that sawdust concrete shows some promise for use in building construction. Hence, it can be utilized as lightweight masonry unit in buildings as a partition wall etc.

\section{FUTURE RECOMMENDATION}

To evaluate the in-depth strength performances including aspects of durability have been putting forward recommendation for future research in direction to discover well indulgent of sawdust as a green building material.

\section{ACKNOWLEDGMENT}

This work was jointly supported by Department of Civil Engineering, Mehran University of Engineering \& Technology, Shaheed Zulfiqar Ali Bhutto Campus, Khairpur Mirs, Pakistan, under FDP Scholarship Scheme, and Faculty of Civil and Environmental Engineering, Universiti Tun Hussein Onn Malaysia, Malaysia.

\section{REFERENCES}

[1] Short, A. and Kinniburgh, W. "Lightweight Concrete", Cr Books Ltd, London. 1998.

[2] Paramasivam, P., and Loke, Y.O.,"Study of Sawdust Concrete", International Journal of Cement Composites and Lightweight Concrete, Volume 2, No. 1, pp. 57-61, 1880 .
[3] Adebakin, I., and Adeyemi, A., "Uses of Sawdust as Admixture in Production of Lowcost and Light-weight Hollow Sandcrete Blocks",American Journal of Scientific and Industrial Research, Volume 3, No.6, pp. 458-463. 2012.

[4] Akinwonmi, A.S.,"Fracture Behaviour of Concrete with Sawdust Replacementunder Uniaxial Compressive", International Journal of Innovative Research \& Development, Volume 1, No.9, pp.155-163.2012.

[5] Moreira A.B.S., Macedo, A.N., and Souza, P.S.L., "Masonry Concrete Block Strength Compound with Sawdust According to Residue Treatment", Acta Scientiarum - Technology, Volume 34, No.3, pp. 269-276. 2012.

[6] Cheng, Y., You, W., Zhang, C., Li, H., and Hu, J., "The Implementation of Waste Sawdust in Concrete", Engineering, Scientific Research, Volume 5, pp. 943-947. 2013.

[7] Saeed, H.H., "Pretreatment of Sawdust for Producing Sawdust Concrete", Journal of Engineering \&Applied Sciences, Volume 31, No.3, pp. 541-549. 2013.

[8] Turgut, P., and Gumuscu, M.,"Thermo-Elastic Properties of Artificial Limestone Bricks with Wood Sawdust", International Science Index, Materials and Metallurgical Engineering, Volume 7, No.4, pp. 235-239, 2013.

[9] Aigbomian, E.P., and Fan, M., "Development of WoodCrete from Hardwood and Softwood Sawdust", The Open Construction and Building Technology Journal, Volume 7, pp. 108-117,2013.

[10] Boob, T.N., "Performance of Sawdust in Low Cost Sandcrete Blocks", American Journal of Engineering Research, Volume 3, No.4, pp. 2320-847,2014.

[11] Kumar, D., Singh, S., Kumar, N., and Gupta, A., "Low Cost Construction Material for Concrete as Sawdust", Global Journal of Researches in Engineering, Volume 14, No. 4, pp. 3428-3430, 2014.

[12] Tomas, U., and Ganiron, Jr.,"Effect of Sawdust as Fine Aggregate in Concrete Mixture for Building Construction", International Journal of Advanced Science and Research, Volume 63, pp. 73-82, 2014. 
[13] Oyedepo, O.J.,Oluwajana, S.D, and Akande, S.P., "Investigation of Properties of Concrete Using Sawdust as Partial Replacement of Sand", Civil and Environmental Research, Volume 6, No.2, pp. 35-42, 2014.

[14] Ambiga K., "Studies on Strength of Concrete by Partial Replacement of Sand with Sawdust", International Journal of Advanced Engineering Research and Studies, Volume 2, pp. 8-10, 2015.

[15] Xing, Z., Djelal, C., Vanhove, Y., and Kada, H., "Wood Waste in Concrete Blocks Made by Vibrocompression”, Environmental Processes, Volume 2, pp. 223-232. 2015.

[16] Chandana, P.S., and Mynuddin, S.A., "Experimental Study on Strength of Concrete by Partial Replacement of Fine Aggregate with Sawdust and Robosand", International Journal and Magazine of Engineering, Technology, Management and Research, Volume 2, No. 9, pp. 338-246, 2015.

[17] Awal, A.S.M., Mariyana, A.A.K., and Hossain, M.Z., "Some Aspects of Physical and Mechanical Properties", International Journal of GEOMATE, Volume 10, No. 21, pp. 1918-1923, Japan, 2016.
[18] Garcez, M.R., Santos, T, Garcez, E.O., Rohden, A.B., "Assessment of Physical and Mechanical Properties of Sawdust Concrete using Ultrasonic Pulse Velocity", Database of Nondestructive Testing (NDT) [ISSN: 14354934], Volume 1, 2016.

[19] Zakaria, N.Z., "Innovative Application of Sawdust Wastage Used as Alternative Sustainable Construction Material", International Journal of Engineering Researches and Management Studies,Volume 3, No. 8, pp. $12-18.2016$.

[20] Wachira, G.G., Gitau, A.N., Kimani, M.W., and Njoroge, B.N.K., "Mechanical Properties of Saw Dust Briquettes of Eucalyptus Tree Species of Different Binders and Press Machines", International Journal of Emerging Technology and Advanced Engineering, Volume 5, No. 4, 2015.

[21] Narayanan, S.P., and Sirajuddin M.,"Properties of Brick Masonry for FE Modeling", American Journal of Engineering Research, Volume 1, pp. 6-11, 2013.

[22] Halil, M.A., and Turgut, P.,"Limestone Dust and Wood Sawdust as Brick Material", Construction and Building Materials, Volume 22, pp. 3399-3403, 2007. 